This article was downloaded by: [Monash University Library]

On: 03 February 2015, At: 00:12

Publisher: Routledge

Informa Ltd Registered in England and Wales Registered Number: 1072954

Registered office: Mortimer House, 37-41 Mortimer Street, London W1T

3J H, UK

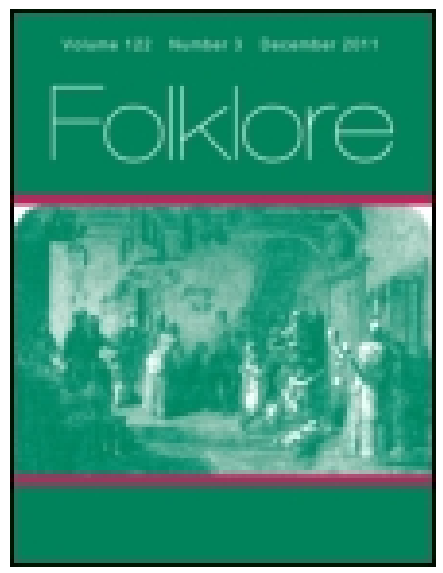

\title{
Folklore
}

Publication details, including instructions for authors and subscription information:

http:// www. tandfonline.com/loi/ rfol20

\section{Battle of Waterloo fought in England.}

L. A. Law

Published online: 06 Feb 2012.

To cite this article: L. A. Law (1900) Battle of Waterloo fought in England., Folklore, 11:4, 458-458, DOI: 10.1080/0015587X.1900.9719602

To link to this article: http:// dx. doi. org/ 10.1080/0015587X.1900.9719602

\section{PLEASE SCROLL DOWN FOR ARTICLE}

Taylor \& Francis makes every effort to ensure the accuracy of all the information (the "Content") contained in the publications on our platform. However, Taylor \& Francis, our agents, and our licensors make no representations or warranties whatsoever as to the accuracy, completeness, or suitability for any purpose of the Content. Any opinions and views expressed in this publication are the opinions and views of the authors, and are not the views of or endorsed by Taylor \& Francis. The accuracy of the Content should not be relied upon and should be independently verified with primary sources of information. Taylor and Francis shall not be liable for any losses, actions, claims, proceedings, demands, costs, expenses, damages, and other liabilities whatsoever or howsoever caused arising directly or indirectly in connection with, in relation to or arising out of the use of the Content.

This article may be used for research, teaching, and private study purposes. Any substantial or systematic reproduction, redistribution, reselling, loan, sub-licensing, systematic supply, or distribution in any form to anyone is 
expressly forbidden. Terms $\&$ Conditions of access and use can be found at http://www.tandfonline.com/page/terms-and-conditions 
house afterwards, the head bricklayer called after the nurse, "The little boy will have no luck with the stone if he don't wet the brick!" When she told me this, I took back the child later in the day with a small coin to give to the friendly bricklayer who had superintended his work, and I found the words "No luck" scribbled upon the brick he had laid.

On our next visit to the house, we found that the words had been smudged out, but after the laying of the date-stone, which we were careful to "butter" with a variety of coins, we noticed that even the smears were carefully washed off.

In my native district (the borders of Shropshire and Staffordshire) this would have been called "paying his foot-ale."

The builder of 'our house tells us that when the first chimney is finished he himself will have to give the men a pint of ale apiece, after which they will hoist a flag on the roof-tree. If they do not get the ale, they will very likely hoist a black flag, and perhaps even refuse to continue the work.

$$
\text { Alice E. Milne. }
$$

\section{Another Sabbath-Breaking Story from Wilts.}

\section{(Cf. p. 347.)}

There was a field near Warminster on which it always rained when the hay was cut. Years ago, the farmer, to induce his men to work on a Sunday in order to get his hay, hid his watch under the last haycock, pretended to have lost it, and set them to search for it. The hay-crop on that field has always been damaged by rain ever since, "so the old men used to tell me,". said G. W., a labouring man from Warminster, from whose narration I noted down this story in June, 1888 .

Charlotte S. Burne.

\section{Battle of Waterloo fought in England.}

Near Thirsk there is a field where folks say that the Battle of Waterloo (1) was fought, when the blood ran over the hoofs of the horses. 